\title{
Increase of Tryptophan Hydroxylase Enzyme Protein by Dexamethasone in Adrenalectomized Rat Midbrain
}

\author{
Efrain C. Azmitia, Baolang Liao, and Yun-shuo Chen \\ Department of Biology, New York University, New York, New York 10003
}

\begin{abstract}
Using two specific anti-peptide antibodies (WH-66 and WH412) against tryptophan hydroxylase (TPH or WH), a single principle band from the midbrain raphe area was seen (approximately $49 \mathrm{kDa}$ ) in Immunoblots. Densitometric comparison of the immunoreactivity of the $49 \mathrm{kDa}$ band was greater $(50-75 \%)$ in immunoblots of midbrain raphe samples from adrenalectomized (ADX) rats given dexamethasone (DEX) in their drinking water $(10 \mathrm{mg} / \mathrm{liter})$ for $12-96 \mathrm{hr}$. No difference from ADX brains was seen in the $49 \mathrm{kDa}$ band after only $4 \mathrm{hr}$ of exposure to DEX in the drinking water. Immunocytochemical staining with WH-66 of sections from rat brainstem showed specific cellular staining in all of the serotonergic raphe nuclei but not in substantia nigra or locus coeruleus. More cellular staining of WH-66-immunoreactive (WH-66-IR) cells was observed in the dorsal and median raphe nuclei in ADX rats given DEX for $72 \mathrm{hr}$, especially in the perikarya and in the primary dendrites. Quantification of staining per cell soma with an automatic image analyzer indicates that amount of WH-66-IR in neurons from both the lateral wing subdivision of the dorsal raphe nucleus and in the supralemniscal nucleus, $B-9$, was $80 \%$ higher in the $A D X+D E X$ compared to $A D X$ animals. Interestingly, morphometric analysis of these same cells showed a corresponding increase of $\mathbf{3 7 - 8 0 \%}$ in somal area. It is suggested that a part of the increase in TPH/WH staining may be a consequence of cellular hypertrophy due to DEX treatment of the ADX rats.
\end{abstract}

[Key words: 5-HT, stress, dorsal raphe nucleus, Western blots, immunocytochemistry, anti-peptide antibodies]

Tryptophan hydroxylase (TPH or WH) is the enzyme that limits the synthesis of 5-HT in the brain and melatonin in the pineal. Antibodies raised against purified TPH/WH have been previously reported by several laboratories (Joh et al., 1975; Cash et al., 1985; Weissmann et al., 1987). These antibodies have the potential to show substantial cross reactivity with phenylalanine hydroxylase (PH) and tyrosine hydroxylase $(\mathrm{TH})$ because of the substantial sequence similarities among the three enzymes. For example, rat $\mathrm{WH}$ has $55.7 \%$ identity with rat $\mathrm{PH}$ and $50.1 \%$ identity with rat TH (Darmon et al., 1986). These authors noted that the greatest homology $(73.3 \%$ with $\mathrm{PH}$ and $71.8 \%$ with $\mathrm{TH})$ occurred in the central part of the molecule [amino acids (aa) 187-324], which contains five conserved cysteines. However,

\footnotetext{
Received Jan. 22, 1993; revised June 2, 1993; accepted June 3, 1993.

This work was supported by NIA P01 AG 10208 and NSF BNS 9013332.

Correspondence should be addressed to Dr. Efrain Azmitia, 10-09 Main Building, New York University, 100 Washington Square East, New York, NY 10003.

Copyright (c) 1993 Society for Neuroscience $0270-6474 / 93 / 135041-15 \$ 05.00 / 0$
}

several sequences in WH were found to be unique for $\mathrm{WH}$, and two of these regions were selected as immunogens for generating WH-specific anti-peptide antibodies.

Antibodies against synthetic peptides have been used to study many previously uncharacterized proteins for which only the cDNA sequence is known. Anti-peptide antibodies can be directed against a specific short region of the molecule, which usually is bound to a larger carrier protein to increase its antigenicity (Hollow and Lane, 1988). We have previously reported success in producing anti-peptide antibodies specific for the $5-\mathrm{HT}_{1 \mathrm{~A}}$ receptor (Azmitia et al., 1992). In the present studies the amino acid sequences were first selected on the basis of non-overlap with sequences in TH and PH. Additional criteria based on the hydrophilicity and secondary structure were also used to arrive at aa 66-91 and aa 412-443, which corresponded to the $\mathrm{N}$-terminus and $\mathrm{C}$-terminus regions of the enzyme. We report that antibodies $\mathrm{WH}-66$ and $\mathrm{WH}-412$ react with a single major band in immunoblots from midbrain raphe tissue, where the serotonergic neurons were highly concentrated (Azmitia, 1978; Jacobs and Azmitia, 1992).

Previous studies had shown that WH activity was higher in stressed animals than in control or stressed adrenalectomized (ADX) rats (Azmitia and McEwen, 1974; Boadle-Biber et al., 1989). Studies using a protein synthesis inhibitor had suggested that at least part of the increased activity was due to de novo protein synthesis (Azmitia et al., 1976; Boadle-Biber et al., 1989; Singh et al., 1990). Does the regulation of $\mathrm{WH}$ by adrenal steroids produce changes in the amount of WH protein present in the serotonergic neurons of the rat midbrain? We now present evidence from immunocytochemical and blot immunolabeling studies that WH protein levels are higher in ADX rats given dexamethasone (DEX) than in ADX rats without steroid replacement.

Abstracts have been previously published (Azmitia et al., 1991; Liao and Azmitia, 1992).

\section{Materials and Methods}

Experimental procedures. Thirty-six female Sprague-Dawley rats (Taconic Farms) weighing about $200 \mathrm{gm}$ were used. Thirty-two rats were anesthetized with ketamine (40 mg/kg; Sigma) and xylazinc $(2.5 \mathrm{mg})$ $\mathrm{kg}$; Sigma), and both adrenals were removed. The ADX rats were maintained with food and $0.9 \% \mathrm{NaCl}$ solution on a $12 \mathrm{hr}: 12 \mathrm{hr}$ light/dark cycle. After 5 or $14 \mathrm{~d}$, the ADX rats were grouped two in each cage, exposed to strong unrythmical sound and $24 \mathrm{hr}$ continuous light, with half of the rats $(n=16)$ receiving DEX (Sigma) at $10 \mathrm{mg} /$ liter in the $0.9 \% \mathrm{NaCl}$ drinking solution for various periods before death. Rats were randomly selected from the ADX and ADX +DEX groups for immunocytochemical versus blot immunolabeling studies. All animals were killed according to NIH guidelines by a protocol approved by the NYU Animal Welfare Committee. 


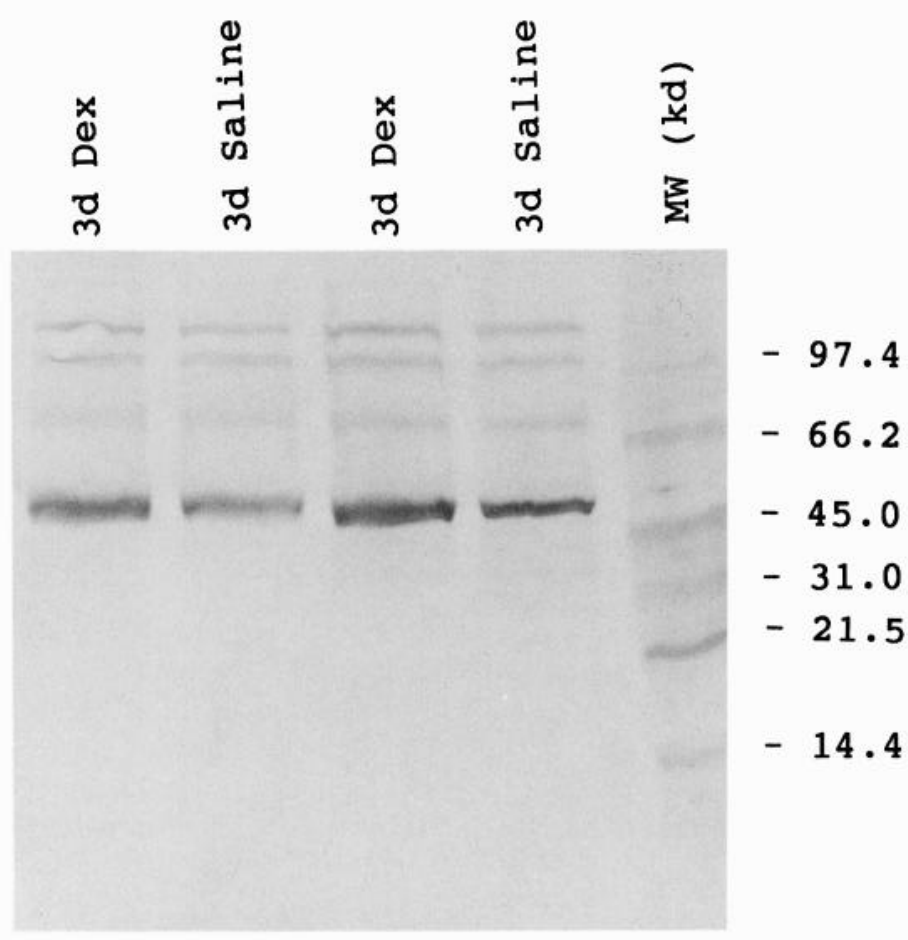

Figure 1. Immunoblots for TPH/WH with antibody WH-412 (1:2000 dilution) using 4-20\% SDS-PAGE run at $125 \mathrm{~V}$ and stained with avidinbiotin peroxidase. The lanes were loaded with $12.5 \mu \mathrm{g}$ (lanes 1 and 2 ) or $25 \mu \mathrm{g}$ (lanes 3 and 4 ) of proteins solubilized from midbrain of rats ADX for $8 \mathrm{~d}$ with or without DEX treatment on the last $3 \mathrm{~d}$. The lanes of midbrain proteins treated with DEX show increased immunoreactivity at both loading concentrations of proteins for the principle band $(\mathrm{MW}=49 \mathrm{kDa})$ and three heavier minor bands. Lane 5 contains lowmolecular-weight biotinylated markers (Bio-Rad).

Immunocytochemistry. Fourteen rats ( 2 control, 6 ADX, and 6 $\mathrm{ADX}+\mathrm{DEX})$ were used for these studies. The control animals were used to establish the staining characteristics of the two antibodies. In the first series of experiments, four ADX rats were kept for $8 \mathrm{~d}$ and two of these given DEX in the drinking saline solution for the last $3 \mathrm{~d}$. In the last experiment, eight animals were selected to compare the response of short- (1 week) and long- ( 2 weeks) term ADX on the effects of giving $3 \mathrm{~d}$ of DEX treatment before death.

All animals were perfused through the ascending aorta with one liter of $4 \%$ paraformaldehyde and $0.1 \% \mathrm{MgSO}_{2}$ in $0.1 \mathrm{~m}$ phosphate buffer (pH 7.4). The brains were postfixed at $5^{\circ} \mathrm{C}$ for at least $4 \mathrm{hr}$ before processed for immunocytochemistry; $60 \mu \mathrm{m}$ coronal sections of the brain were cut on a Vibratome (Oxford) and incubated in primary antiserum (WH-66, 1:500 to 1:50,000, 16-24 hr at room temperature) diluted in $0.1 \mathrm{~m}$ Tris-HCl-buffered (pH 7.6) saline (TBS) containing $1 \%$ normal sheep serum and $0.1 \%$ Triton $\mathrm{X}-100$. Immunoreactivity was visualized with the elite Vectastain $A B C$ kit. The reaction was run for $6 \mathrm{~min}$ at room temperature in $0.05 \%$ 3,3-diaminobenzidine (Sigma) with $0.01 \% \mathrm{H}_{2} \mathrm{O}_{2}$ and terminated by rinsing with TBS. Optimal staining was produced by dilutions between 1:7500 and 1:20,000 of the WH66. Photographs were taken with a Leitz Orthoplan microscope using planar apochromatic lens and Kodak TMax 100 ASA film. Measurements of the intensity of WH-66-immunoreactive (-IR) and somal area of neurons from slides were made with a Leitz oil $63 \times / 1.40$ Planapo objective on a Zeiss Axioplat microscope and Optimas image analysis system by Bioscan, Inc.

Blot immunolabeling. Twenty-two rats were used and 20 were utilized for the ADX studies and two control brains used to establish the immunoblot procedure. Four ADX rats were maintained for $8 \mathrm{~d}$ with free access to $0.9 \%$ saline solution and two of the rats were given DEX for the last $3 \mathrm{~d}$ before the animals were killed. Sixteen ADX animals were used to determine the time course of DEX treatment begun $5 \mathrm{~d}$ after ADX with DEX added to the drinking water for $4 \mathrm{hr}$, and $1,2,3$, or $10 \mathrm{~d}$ before death. The animals were decapitated under ether anesthesia and their brains were rapidly removed, dissected, frozen on dry ice, and stored in $-70^{\circ} \mathrm{C}$. The midbrain raphe was dissected with the rostral border extending from the anterior end of the superior colliculus ventrally to the posterior end of mammillary body and the caudal border extending from the posterior end of the inferior colliculus ventrally to the anterior ridge of the pons. A horizontal cut was made at the level of the cerebral aqueduct to remove the tectum, and the lateral boundaries were established by cuts $2 \mathrm{~mm}$ on either side of the midline.

The stored midbrain raphe samples were transferred to the lysis buffer, made from highest grade chemicals from Sigma and Boehringer-Mannheim (Azmitia et al., 1992). Samples were homogenized by hand in a $1.5 \mathrm{ml}$ polypropylene microcentrifuge tube and allowed to sit for 15 min on ice before spinning in a microcentrifuge (Eppendorf 5415) at $10,000 \mathrm{rpm}$ for $10 \mathrm{~min}$ at $5^{\circ} \mathrm{C}$. The supernatants were collected and protein concentrations (Bio-Rad dye-binding assay against BSA standard) adjusted to $2 \mathrm{mg} / \mathrm{ml}$ with $0.1 \mathrm{M}$ TBS. Samples were heated after adding Laemmli sample buffer with $\beta$-mercaptoethanol and subjected
Figure 2. Western blots for TPH/WH with antibody WH-412 (1:2000) using $10 \%$ SDS-PAGE. Lane 1 is the biotinylated heavy-molecular-weight marker. Lanes 2-9 represent the times of treatment of $0.9 \%$ saline or DEX to rats ADX for $5 \mathrm{~d}$. Increase immunoreactivity was seen in the principle band at 49 $\mathrm{kDa}$ and the three heavier minor bands after $1 \mathrm{~d}$ (lanes 2 and 3 ). The differences in immunostaining between saline- and DEX-treated brains were maximal at 2-10 d.

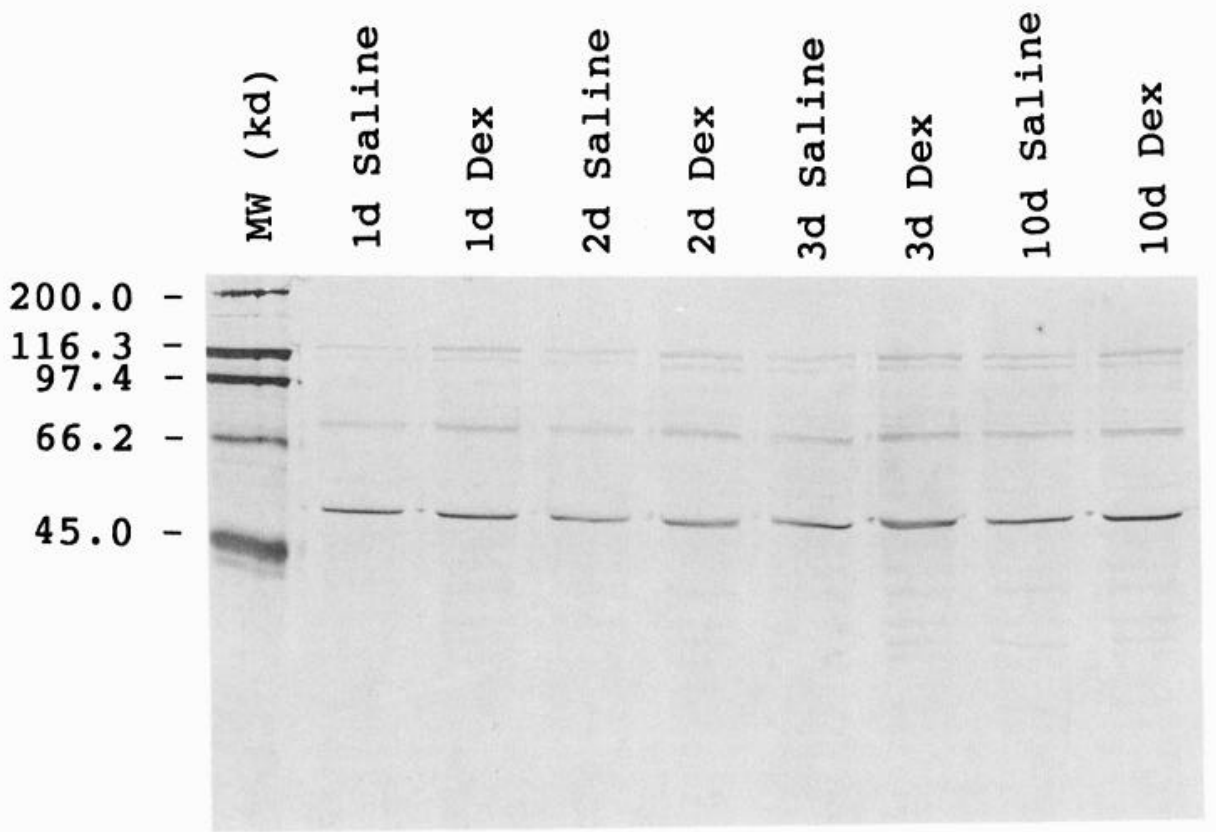




\section{ROSTRAL DRN}
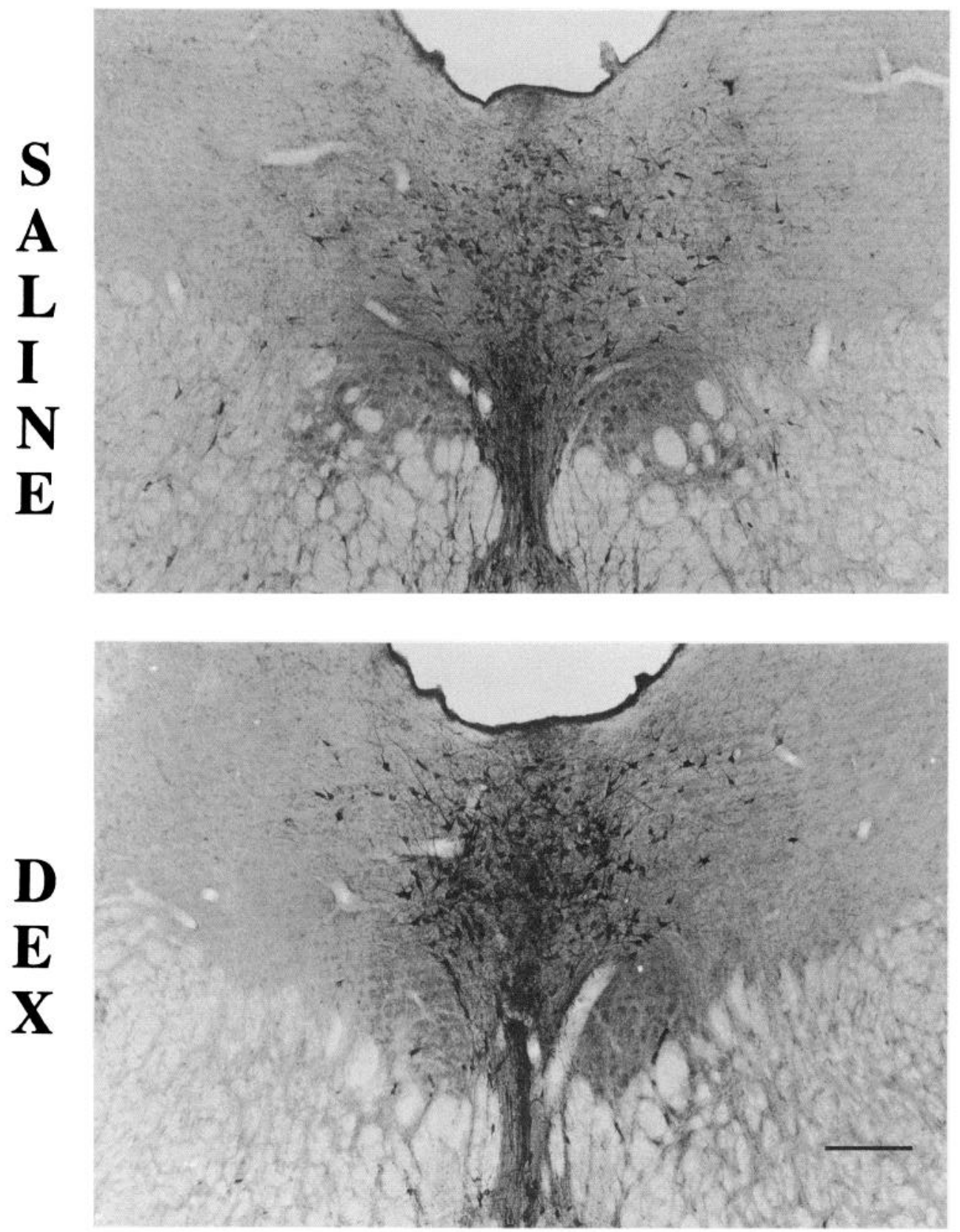

Figure 3. Photographs of the rostral DRN at the level of the oculomotor motor nucleus in ADX rats $(8 \mathrm{~d})$ treated with or without DEX for the last $3 \mathrm{~d}$. The neurons were stained with the WH66 antibody (1:7500). The staining of the nucleus can be clearly seen in both animals. However, the intensity and density of staining appears greater in the animal given DEX. This was especially clear along the midline of the nucleus and just below the cerebral aqueduct. Scale bar, $200 \mu \mathrm{m}$. to SDS-PAGE $10 \%$ and $4-20 \%$ slab gels at $125 \mathrm{~V}$. Proteins were transferred electrophoretically $(100 \mathrm{~V}, 1 \mathrm{hr})$ to nitrocellulose membrane $(0.45$ $\mu$; Bio-Rad) at $5^{\circ} \mathrm{C}$ using a Bio-Rad Trans Blot Cell.

Nitrocellulose sheets were incubated overnight with antiserum WH $412(1: 2000)$ in $0.1 \mathrm{~m}$ TBS (pH 7.6) with $0.1 \%$ (v/v) Tween-20 (Sigma) (TTBS). The sheets were rinsed in TTBS for $10 \mathrm{~min}$ three times between the reactions with biotinylated goat anti-rabbit IgG (Boehringer-Mannheim) (60 min incubation), streptavidin-horseradish peroxidase conjugate (Boehringer-Mannheim) (60 min incubation), and 0.05\% diaminobenzidine (DAB) in TBS, $0.2 \%$ nickel ammonium sulfate (Fisher), and $0.01 \%(\mathrm{v} / \mathrm{v}) \mathrm{H}_{2} \mathrm{O}_{2}(5-10 \mathrm{~min})$. The nitrocellulose sheets were photographed using a Leitz camera with TMax 100 film. The negatives were scanned using a soft laser scanning densitometer (model SLR-504-XL; Biomedical Instruments Inc., Fullerton, CA).

\section{Results}

Blot immunolabeling studies

Anti-peptide antibodies WH-66 and WH-412 were used at dilutions of $1 / 7500$ and $1 / 2000$, respectively, to immunostain nitrocellulose strips of electrophoretic transfers midbrain raphe subjected to SDS-PAGE on slab gels. The midbrain extract was run at two different protein amounts $(25$ and $12.5 \mu \mathrm{g})$ on the SDS gels. Antibodies WH-66 and WH-412 produced similar patterns of immunoreactivity although the bands appeared sharper and more easily resolved with the WH-412 than with the WH-66 antibody. The staining pattern obtained with the 


\section{DORSAL RAPHE NUCLEUS}

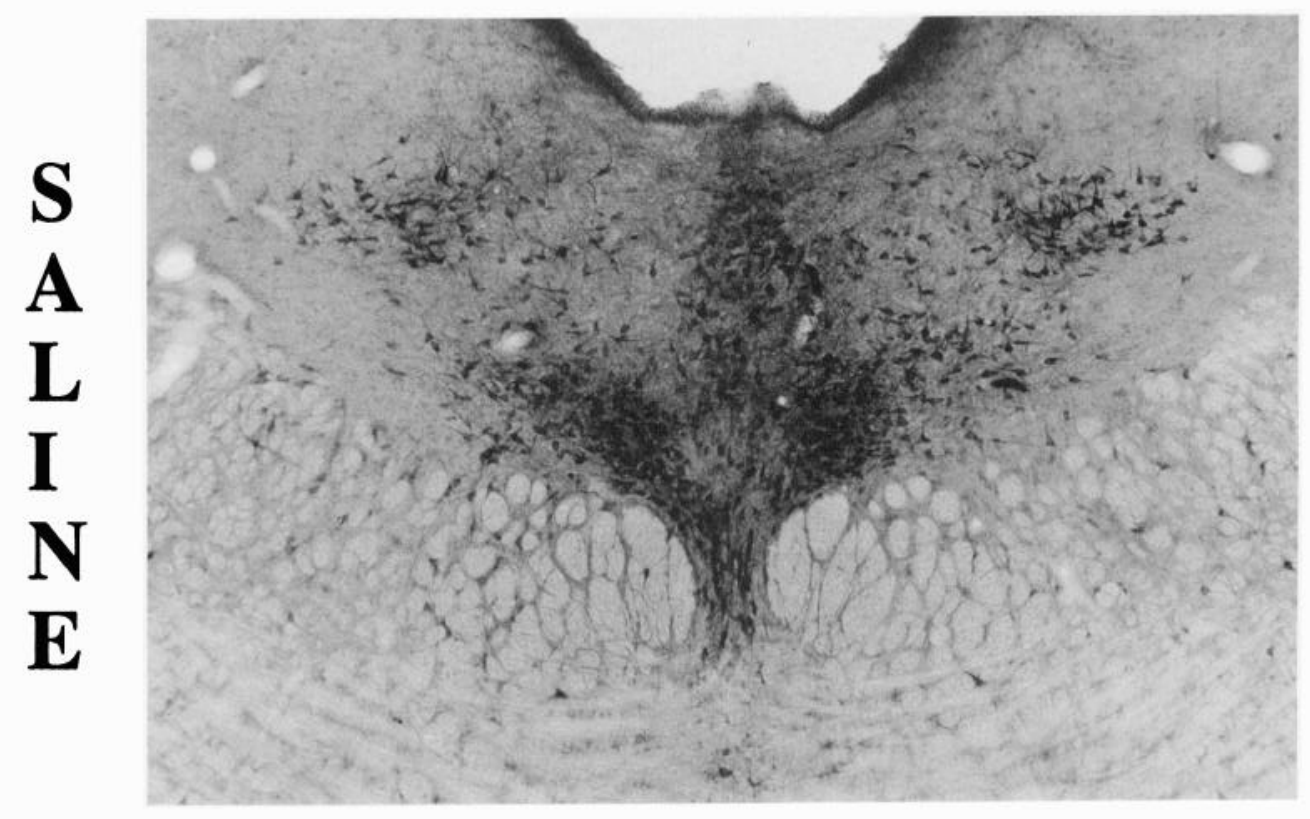

Figure 4. Photographs of the DRN at its most developed extent. The four main subdivisions were clearly shown. The centromedian subdivision is directly below the cerebral aqueduct. The interfascicular subdivision is funnel shaped and between the medial longitudinal fasciculus. The bilateral lateral group of WH-66-IR neurons comprise the lateral wing subdivisions. Individual WH-66-IR neurons can be seen in the saline-treated animals throughout the three major subdivisions. However, in the DEX-treated animals, the density of WH-66-IR label obscures the individual cells in all subdivisions. This was especially obvious in the midline of the interfascicular subdivision. Scale bar, $200 \mu \mathrm{m}$.

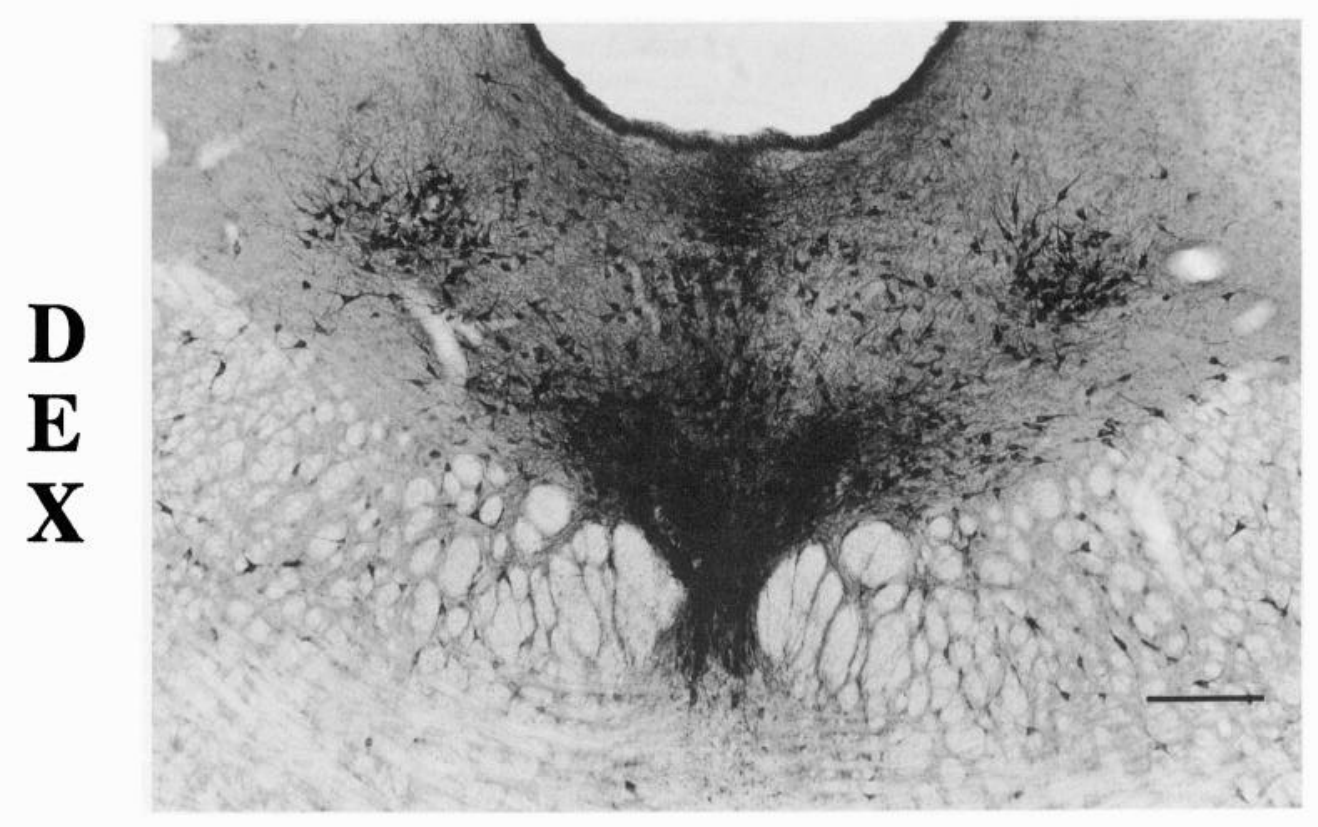

WH-412 antibody is shown in Figure 1. A single major band of approximately $49 \mathrm{kDa}$ was visible in lanes from saline- and DEX-treated tissues. Several minor bands were apparent at higher molecular weights (approximately 73, 100, and $116 \mathrm{kDa}$ ).

In the first series of studies the animals were ADX for $8 \mathrm{~d}$ and half the rats were given DEX in the drinking solution (10 $\mu \mathrm{g} / \mathrm{ml}$ saline) for the last $3 \mathrm{~d}$. Comparison of the raphe tissue lanes from saline-treated and DEX-treated animals showed more dense staining of the $49 \mathrm{kDa}$ band after DEX treatment (Fig. 1). This was apparent after loading with either 12.5 or $25 \mu \mathrm{g}$ of protein. It also appeared that the higher-molecular-weight bands were similarly increased after DEX treatment (Fig. 1). Densi- tometric analysis of staining intensity measure in the $49 \mathrm{kDa}$ bands showed a DEX-induced increase of $72 \%$ and $45 \%$ in the 12.5 and $25 \mu \mathrm{g}$ lanes, respectively, compared to saline-ADX control animals.

The time course of the DEX-induced increase in staining of the gels was tested by making protein extracts after $4 \mathrm{hr}$ and 1 , 2,3 , or $10 \mathrm{~d}$ of DEX treatment to rats that were ADX $5 \mathrm{~d}$ before steroid treatment (Fig. 2). The results with loading $10 \mu \mathrm{g}$ of protein showed that the difference in the major band between DEX and saline treatment was not seen after $4 \mathrm{hr}$, but was apparent after $1 \mathrm{~d}$ of treatment with a difference in the density of $32 \%$. The difference after $2 \mathrm{~d}$ was $53 \%$, and no further increase 


\section{CAUDAL DRN/MRN}
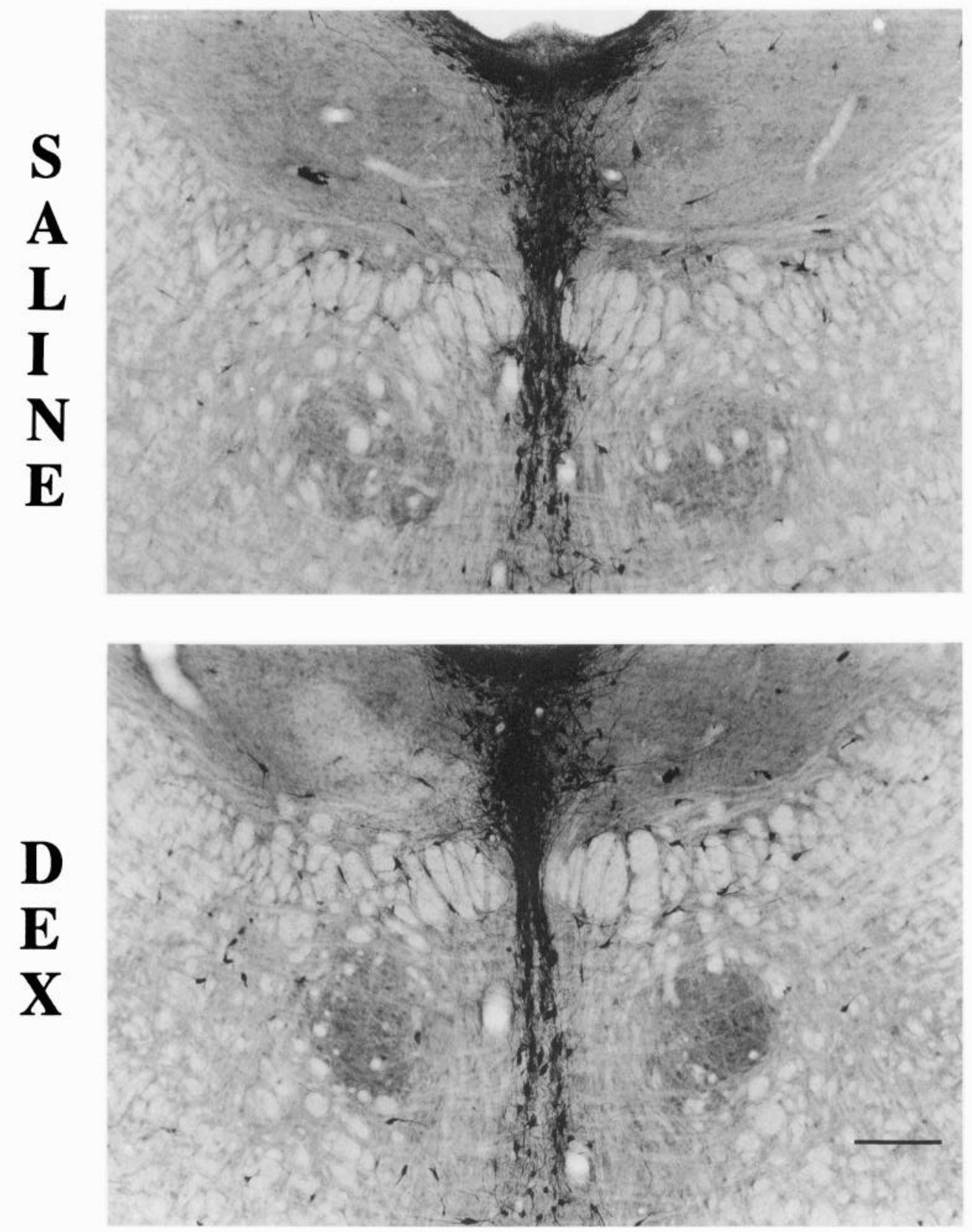

Figure 5. Photographs of the caudal DRN and the MRN at the level of the ventral nucleus of Gudden ventrolateral to the medial longitudinal fasciculi. Notice at this level that the interfascicular subdivisions of the DRN and MRN are fused (this grouping was termed the nucleus centralis superior). Comparison of the two photographs shows that individual cells appear to be equally reactive in both saline- and DEX-treated ADX rats. However, as seen in the previous sections, the midline zone especially in the DRN was more dense after DEX treatment. Scale bar, $200 \mu \mathrm{m}$. was noted after either 3 or $10 \mathrm{~d}$ ( $52 \%$ and $48 \%$, respectively). The high-molecular-weight minor bands also showed an apparent increase after a single day of DEX treatment.

\section{Immunocytochemistry of brainstem sections}

Serial sections were made through the brainstem of saline- and DEX-treated ADX animals to include the entire superior groups of 5-HT-containing neurons. Antibodies against WH-66 showed specific DAB staining compared to preimmune staining at dilution from 1:1000 to 1:50,000, with the best labeling at a dilution of 1:7500. The preimmune serum for WH-66 showed no specific staining at any dilution. WH-412 showed no specific staining over a wide range of dilutions (1:500 to 1:50,000).
WH-66-IR cell bodies and dendrites were clearly seen in all nuclei previously reported to contain 5-HT. No specific cellular staining was seen in the substantia nigra or in the locus coeruleus. Detailed immunocytochemical analysis was performed on the main ascending 5-HT-containing nuclei in the midbrain and rostral pons. These included the dorsal raphe nucleus (DRN) from its most rostral to its caudal extent (Figs. 3-5, respectively), the median raphe nucleus (MRN) at its rostral (Fig. 6) and caudal end (Fig. 5), and the ventrolateral supralemniscal nucleus [SLN (B9), Fig. 6]. The principle subdivisions of the DRN were all filled with WH-66-IR neurons; the lateral wings located dorsolateral to the medial longitudinal fasciculus (Fig. 7), the centromedian cluster located on the midline immediately below 


\section{ROSTRAL MRN \& SLN}

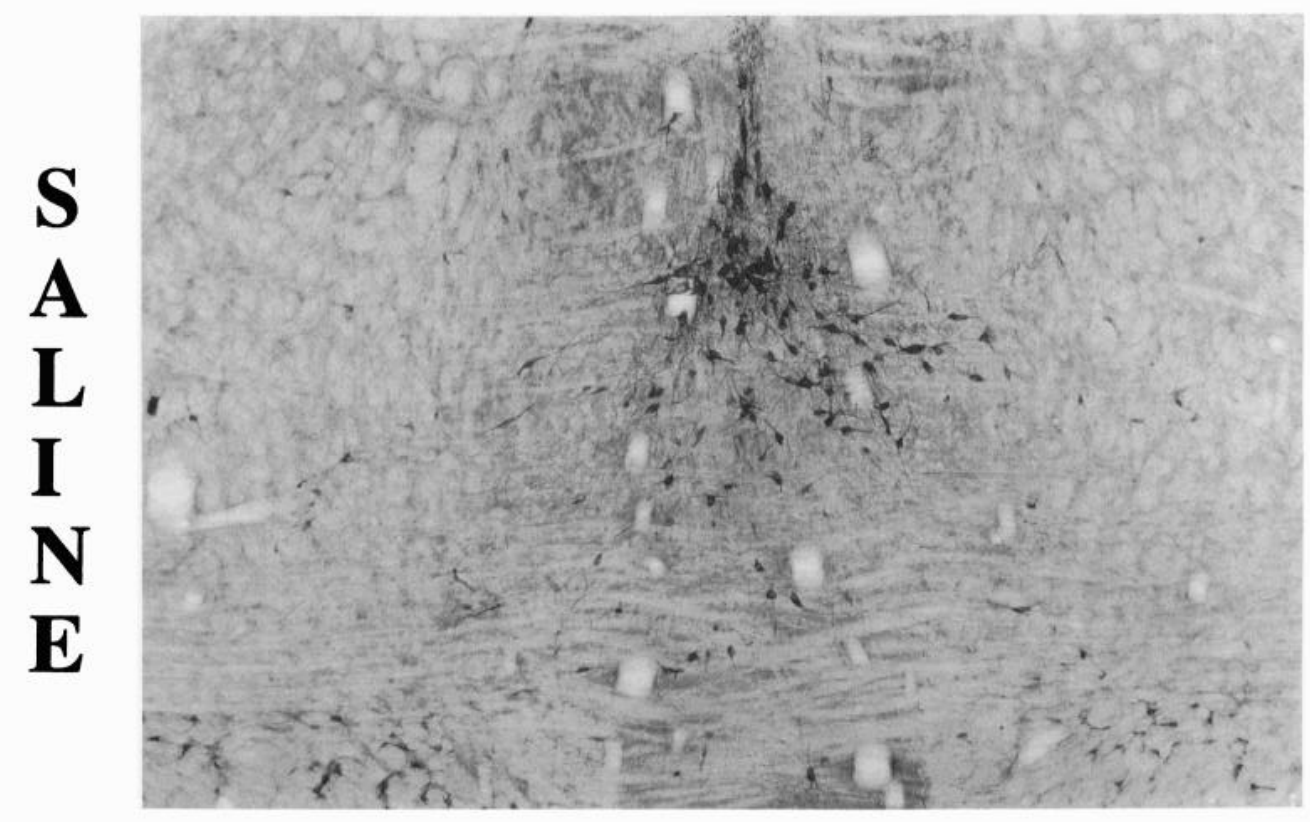

Figure 6. Photograph of the rostral

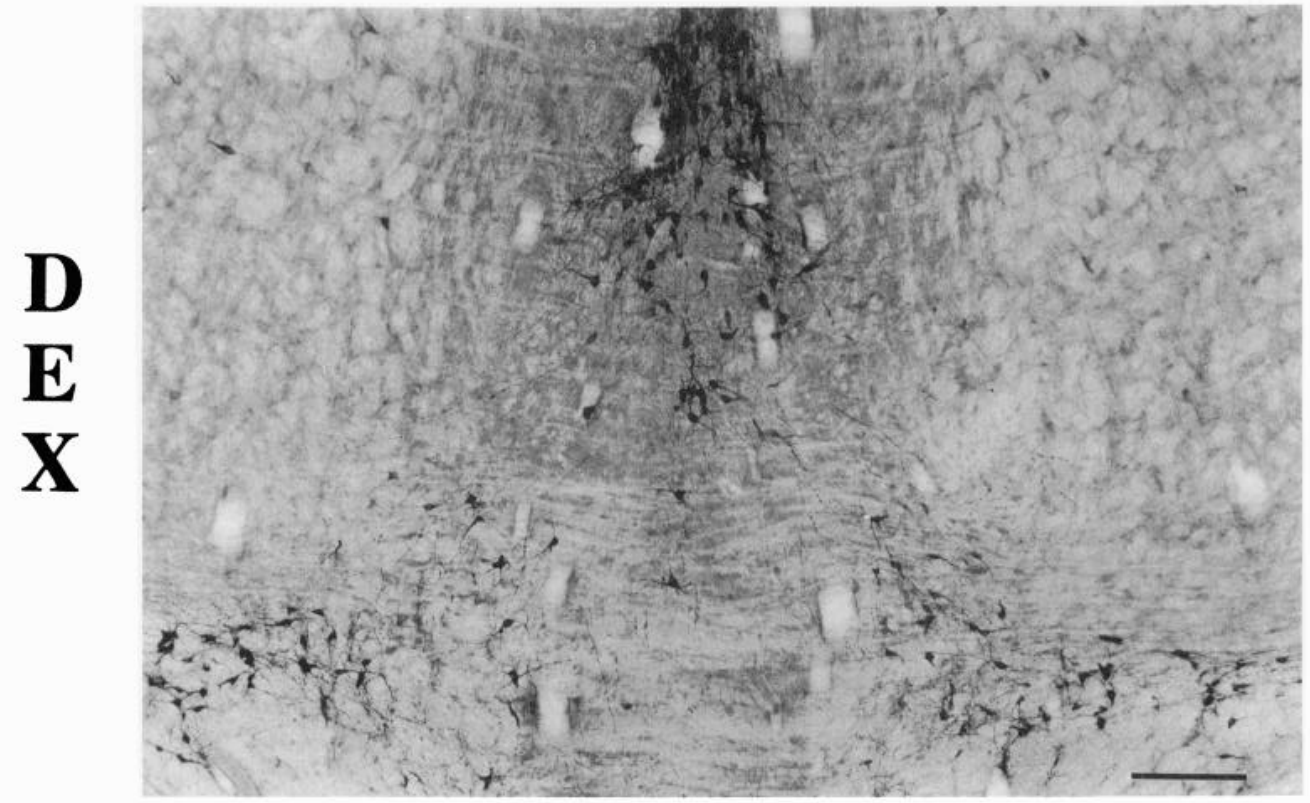
MRN just dorsal to the decussating fibers of the brachium conjunctium and the ventrolaterally stretching cells of the SLN (B9) immediately dorsal to the medial lemniscal fibers. The cellular and nuclear pattern of WH-66-IR neurons appears similar in the MRN, but a markedly increase level of staining was seen in the SLN. Scale bar, $100 \mu \mathrm{m}$.

the cerebral aqueduct (Fig. 8), and the interfasciculus group located immediately above and between the MLF (Fig. 9). The cellular labeling in the lateral wings of DRN (Fig. 10) and in the SLN (Fig. 11) with WH-66 at high-power magnification was localized mainly to the cytoplasm and the dendritic branches with the nucleus unlabeled.

Comparisons were made in the immunocytochemical staining pattern in ADX rats with or without $3 \mathrm{~d}$ of DEX treatment. The intensity of WH-66-IR staining was much greater in DEXtreated rats in all areas examined. The main body of the DRN (Fig. 4) and the rostral DRN (Fig. 3) showed clear differences in the staining level between ADX rats given saline alone or with DEX. In the main DRN of ADX rats, the immunoreactive neurons were clearly discernable as separate cells, even in the interfasciculus and centromedian subdivisions. However, in the DEX-treated animals, the staining was so intense that individual cells were often hard to locate in these two areas at this magnification. The staining in the rostral DRN (Fig. 3), at the level of the trochlear nucleus, and the caudal DRN (Fig. 5), at the level of the ventral tegmental nucleus, were compared. The saline- and DEX-treated rats were again different, with the DEXtreated brains showing more intensity of staining especially in the midline areas. The comparison of the MRN labeling at both rostral (Fig. 6) and caudal levels (Fig. 5) did not show the striking 


\section{DRN, LATERAL WINGS}
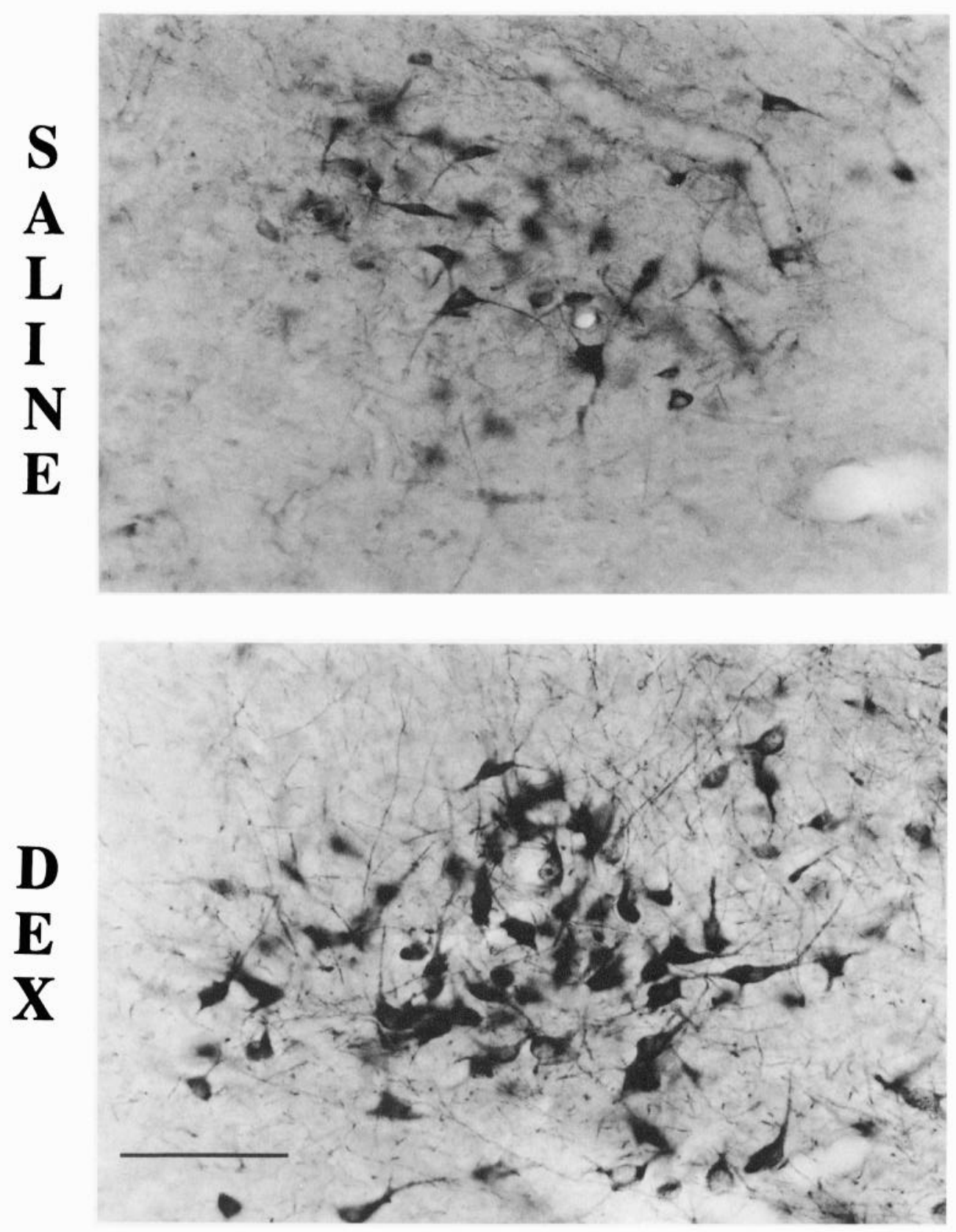

Figure 7. Photograph taken at a higher magnification $(250 \times)$ of the lateral wing subdivision of the DRN. The WH66-IR neurons look equally stained, but the size seems larger and the branching more extensive after DEX treatment. Note the large number of dendrites branching from the soma of DEX-treated neurons compared to the saline control. Scale bar, $100 \mu \mathrm{m}$. differences seen in the DRN cells. However, the WH-66-IR neurons in SLN (B-9), which extends ventrolaterally from the MRN, showed a much greater intensity of staining in the DEXtreated ADX rats (Fig. 6).

Higher-magnification examination of the subdivisions of the DRN was performed. The lateral wing WH-66-IR neurons in the saline-treated brains showed poorly stained cell bodies and short processes extending from the neurons (Fig. 7). In contrast, the lateral wing WH-66-IR neurons in the DEX-treated brains appeared more intensely stained in the cytoplasm and in the proximal dendrites (Fig. 7). In addition, a number of long, fine fibers projected between and from these labeled neurons in the
DEX-treated rats. A similar pattern was seen in the centromedian cluster (Fig. 8). The most striking change after DEX treatment to ADX rats could be seen in the fine fiber plexus above the labeled cells immediately below the cerebral aqueduct where the DEX-treated section showed intense labeling. Finally, in the interfascicular group of WH-66-IR neurons from the ADX rats, a large number of moderate- to heavy-stained cells were seen, a few with long processes (Fig. 9). In comparison, the WH-66-IR staining in the DEX-treated brain was more intense and in places individual cells were difficult to resolve. Note the very large number of processes between the cells in the DEX-treated compared to the saline-treated ADX brains. 


\section{DRN, CENTROMEDIAN}
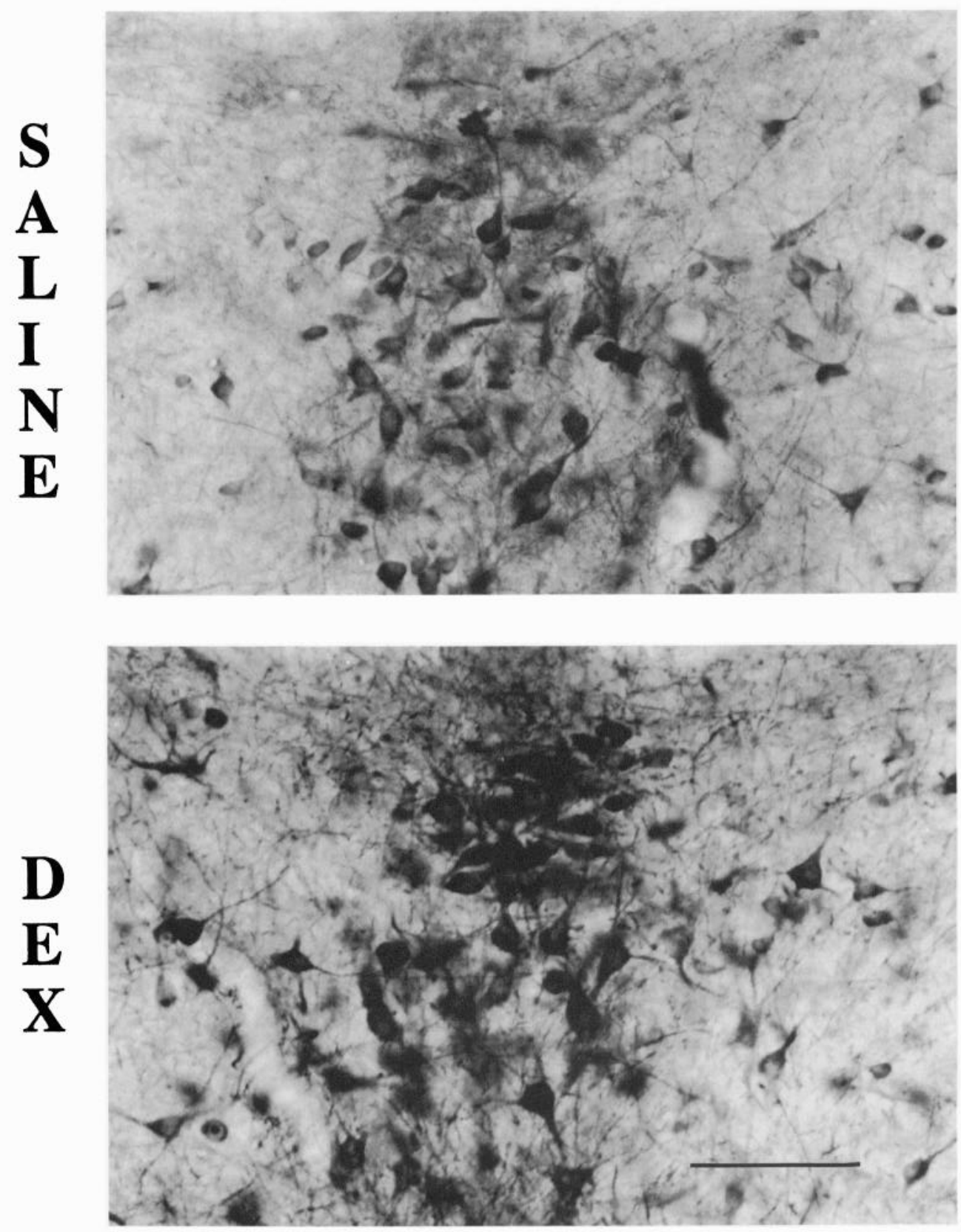

Figure 8. Photograph taken at $250 \times$ of the centromedian subdivision of the DRN. The WH-66-IR neurons lie below the cerebral aqueduct and individual neurons appear equally dark in both sections from the saline- and DEXtreated ADX animals. Noticeably, more dendrites and unidentified processes were seen immediately beneath the cerebral aqueduct in the DEX-treated brain. Scale bar, $100 \mu \mathrm{m}$.

Oil high-magnification (Leitz $63 \times / 1.40$ Planapo) examination of the lateral wing subdivision of the DRN (Fig. 10) and the SLN (B9) (Fig. 11) compares individual cells from the salineand DEX-treated brains. In the saline-treated brains, the cells show heterogeneous label with some cells darkly and the others lightly labeled. The label was mainly in the perikaryon with short, thin processes emanating from the cell body. In contrast, the DEX-treated neurons in both areas (Figs. 10,11) were more uniformly heavily labeled and thick, often bulbous, processes extending from the cytoplasm. The photograph of the lateral wing neurons of the DEX-treated brains (Fig. 10) illustrates many examples of WH-66-IR bulbous fibers. In the SLN (B9), several of the WH-66-IR processes also have enlarged varicos- ities that extend from the cell body. Finally, the size of cell body and primary dendrites of the WH-66-IR labeled neurons in the DEX-treated animals in both areas appeared to be larger.

In order to determine if long-term ADX rats responded differently to DEX treatment than short-term ADX rats, ADX rats were maintained on saline solution alone for either 1 (short) or 2 weeks before DEX was added to the drinking for $3 \mathrm{~d}$. The increase in immunostaining described above was again seen in the short-term ADX rats when given DEX in the saline drinking water (Fig. 12). However, in the long-term ADX animals, the staining was weaker in both the ADX rats given saline alone and after DEX treatment (Fig. 13). Nevertheless, the difference between saline alone and saline with DEX in the drinking water 


\section{DRN, INTERFASCICULUS}
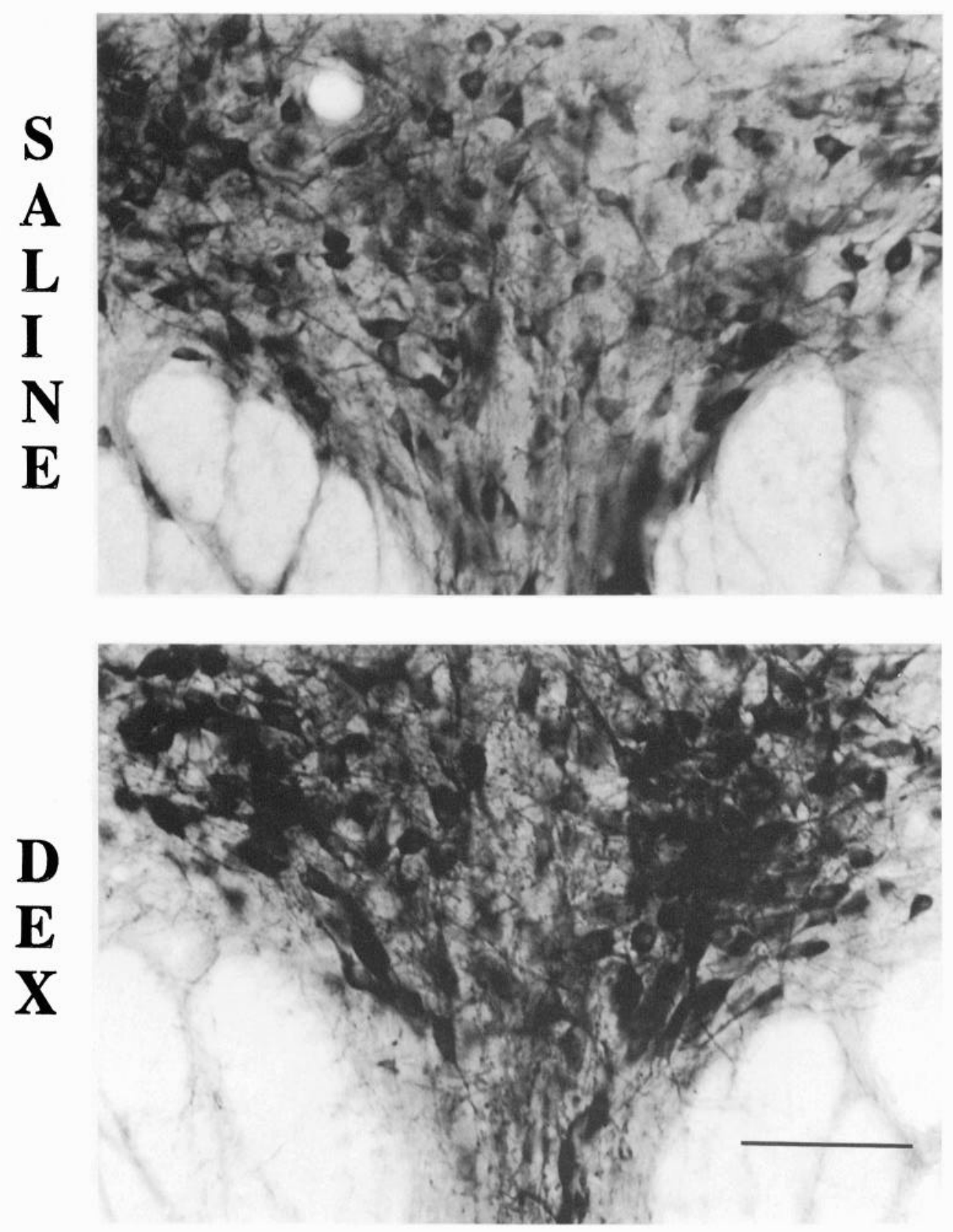

Figure 9. Photograph taken at $250 \times$ of the interfascicular subdivision of the DRN. Many WH-66-IR neurons can be seen in the section from the ADX animals maintained with saline solution. The soma labeling does not stain the nucleus, which was clearly seen as a clear circle in a number of the neurons. There was substantially more WH-66-IR after DEX in this area and individual cells were difficult to identify. WH-66-IR processes within this subdivision appeared more numerous after DEX treatment. Scale bar, $100 \mu \mathrm{m}$. was still apparent in the WH-66-IR staining pattern in raphe nuclei, especially in the lateral wings of the DRN of the shortterm ADX+DEX.

\section{Morphometric analysis}

The increase staining observed at high magnification (see Figs. 10, 11) after ADX in the short-term ADX + DEX appeared to be accompanied by an increase in neuronal size. Image intensity measurements of the cellular WH-66-IR quantity and morphometric analysis of soma area were performed in selected neurons from the lateral wings of the DRN and the neurons in SLN (Table 1). The WH-66-IR level in individual neurons was in- creased after treatment with DEX by $80 \%$ in the DRN-lateral wing ( $p<0.05$ ) and by $76 \%$ in the SLN (B9). In conjunction, the soma area $\left(\mu \mathrm{m}^{2}\right)$ measurements of these same WH-66-IR neurons showed that the area in the ADX +DEX was increased by $79 \%$ in the DRN-lateral wing $(p<0.05)$ and by $37 \%$ in the SLN (B9) compared to ADX rats maintained on saline alone. If these results were expressed as a ratio of the amount of WH66-IR divided by the area for each neuron, the significant differences seen in DRN-lateral wing was no longer present. In fact, the ratios were essentially the same between the two groups (ADX + DEX was $101 \%$ of ADX alone). A similar, but not as dramatic, decrease in the differences seen when the results were expressed as a ratio in the SLN (B9) neurons. 


\section{DRN, LATERAL WINGS}

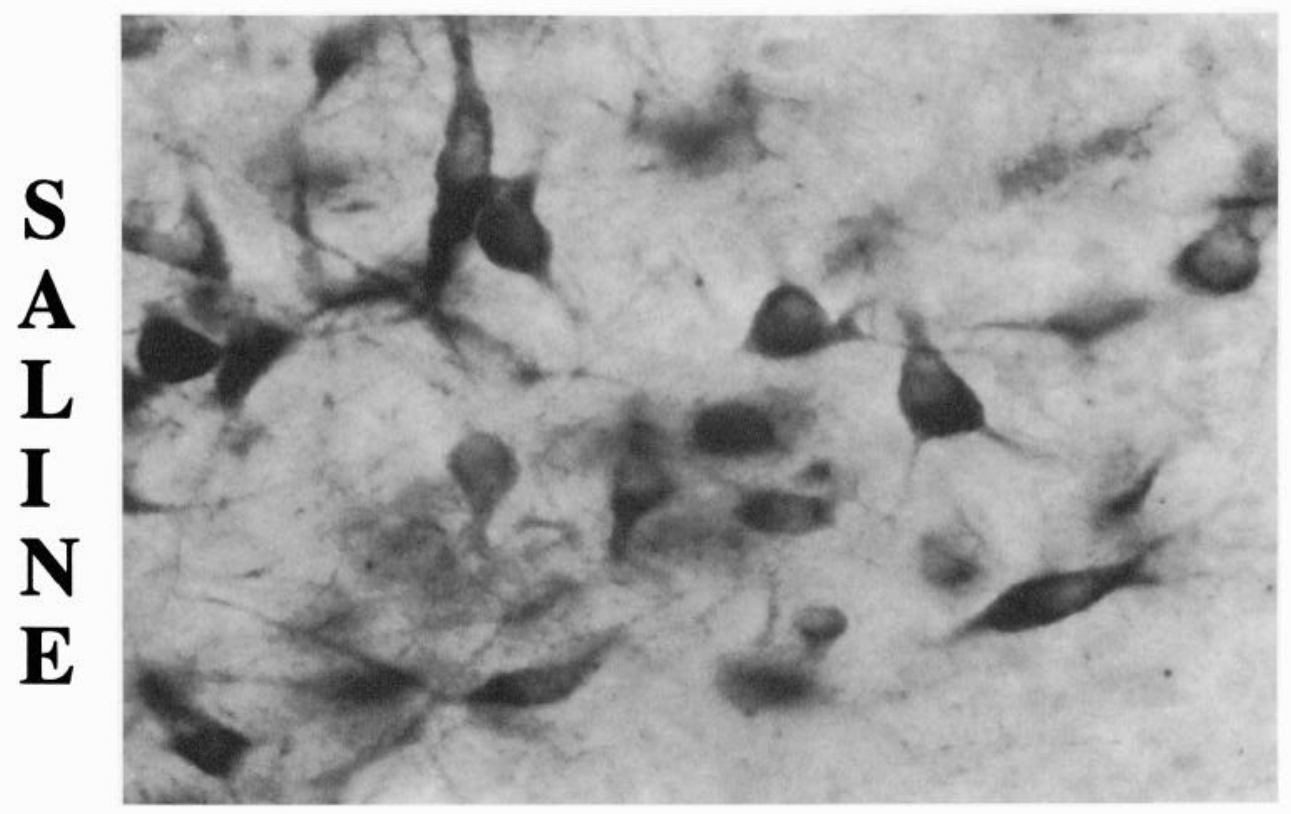

Figure 10. Photograph at highest magnification taken at $630 \times$ of WH66-IR neurons in the lateral wing subdivision of DRN. Individual cellular labeling was easily seen in ADX rats given saline alone or with DEX. The WH-66-IR neurons in the saline-treated brains were fusiform or oval with few thin processes emanating from the soma. The cell nucleus can be seen to be unlabeled. The neurons of the DEX brain appear more pyramidal in shape and with more pronounced bulbous dendrites extending from the soma. The nucleus was also unlabeled in these neurons. Scale bar, $30 \mu \mathrm{m}$.

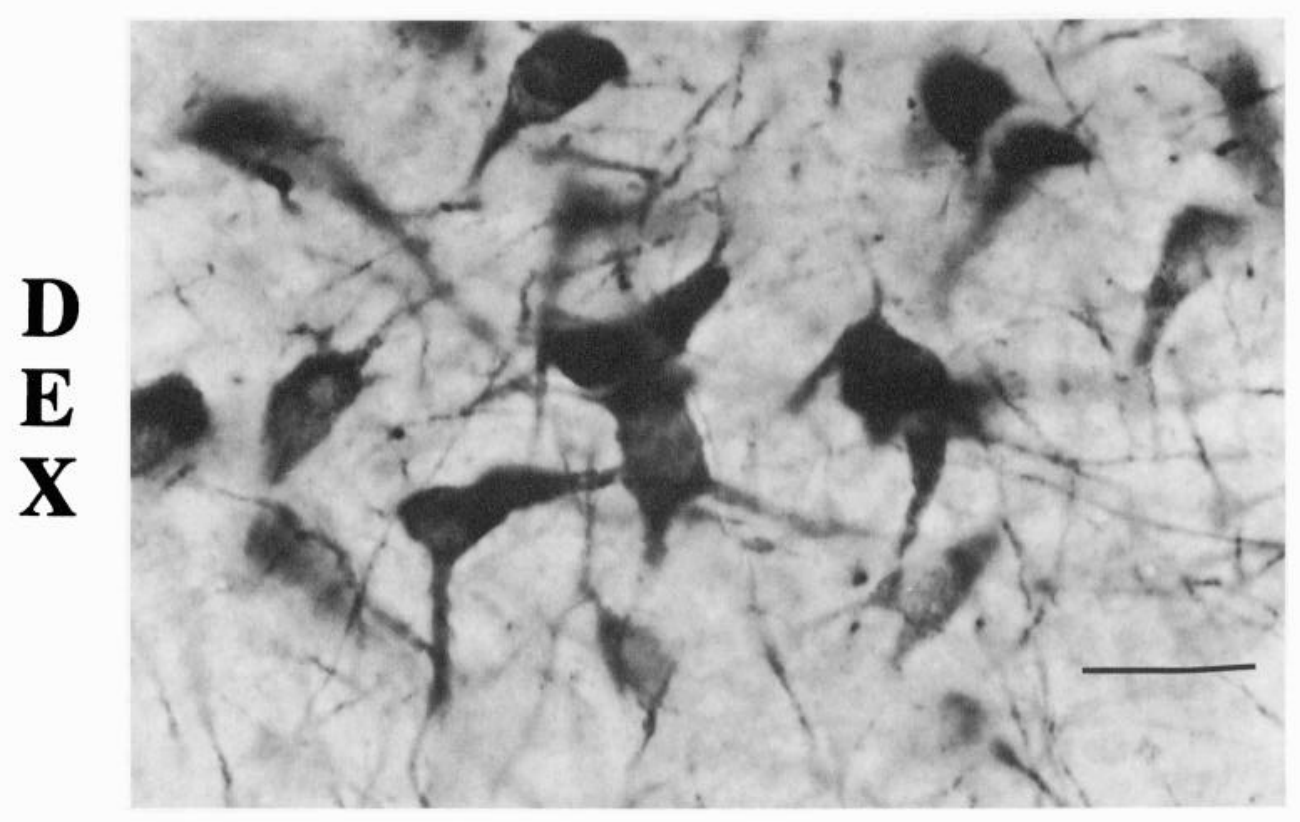

\section{Discussion}

The availability of a rodent TPH/WH-specific antibody with no cross-reactivity for TH has made this study possible. The peptide sequences selected for raising the two anti-peptide antibodies against WH showed no homology with the sequences of TH and PH (Darmon et al., 1986), and no specific staining was seen in brain nuclei that contain $\mathrm{TH}$, the substantia nigra and locus coeruleus. Thus, the results presented in this report deal only with the changes in $\mathrm{WH}$, the rate-limiting enzyme for 5 -HT biosynthesis. Polyclonal antibodies raised against the whole WH protein have shown considerable cross-reactivity with both TH and PH (see Cash et al., 1985). A monoclonal antibody raised against $\mathrm{PH}$ from monkey liver (PH8) stains WH but not $\mathrm{TH}$ in human brain fixed with $4 \%$ paraformaldehyde and paraffin embedded, and in rat brain sections the PH8 antibody labels TH as well as WH (Haan et al., 1987; Törk et al., 1992). Among the two anti-peptide antibodies that we made against WH, WH-412 was more sensitive for immunoblotting analysis and only WH-66 was useful for immunocytochemistry of rat brain sections.

Rat WH has a predicted molecular weight of $51,010 \mathrm{Da}$ (Darmon et al., 1988). Running SDS-PAGE gels with midbrain raphe tissue under reducing and denaturing conditions produced a single principle band with an apparent molecular weight of 49 $\mathrm{kDa}$. A series of higher-molecular-weight bands, heavily labeled 


\section{SUPRALEMNISCAL NUC.}
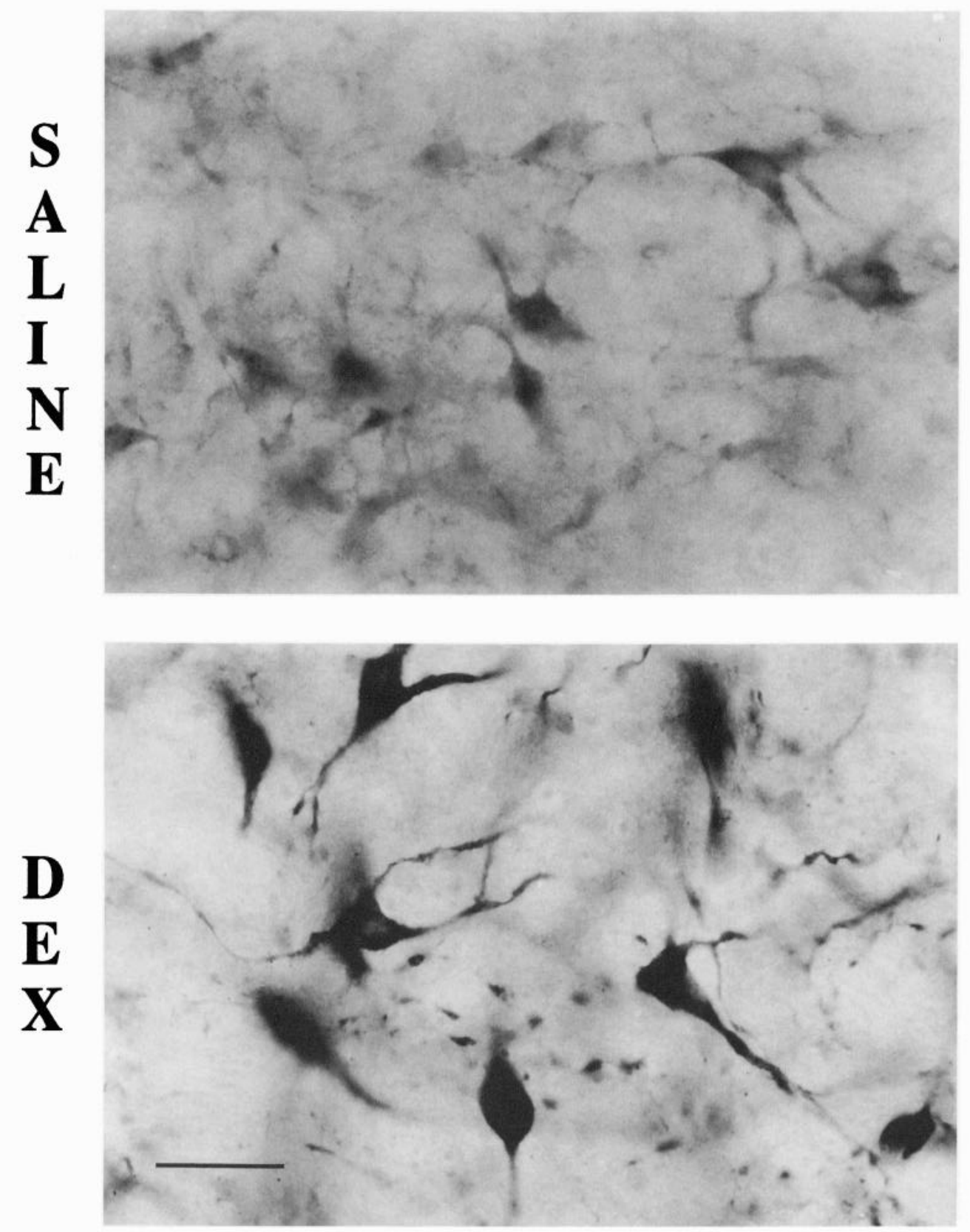

Figure 11. Photograph taken at $630 \times$ of WH-66-IR neurons in the SLN (B9). The cells were weakly stained with the WH-66 antibody in the ADX animals given only saline. The cells were multipolar but the dendrites were short and tapered. The WH-66-IR neurons in the DEX-treated brain were darker staining and multipolar with thick, often bulbous, dendrites extending from the soma. Heavily labeling varicose fibers (axons) were easily seen extending from the soma and running though the area. Scale bar, $30 \mu \mathrm{m}$. in nonreducing conditions (data not shown), were lightly stained in our gel (see Figs. 1, 2). There is evidence that WH exists as a protein complex with a molecular weight of $288 \mathrm{kDa}$ and 300 $\mathrm{kDa}$ composed of proteins of $59 \mathrm{kDa}$ (Nakata and Fujisawa, 1982). These results indicate that WH exists as a tetramer of four identical subunits, and in a cross-linking experiment with purified WH, SDS-PAGE showed bands of $45 \mathrm{kDa}, 90 \mathrm{kDa}$, $135 \mathrm{kDa}, 180 \mathrm{kDa}, 225 \mathrm{kDa}$, and $270 \mathrm{kDa}$. In our studies, midbrain raphe brain tissue produced a single principle band of $49 \mathrm{kDa}$ in normal and ADX rats with minor bands at 73 $\mathrm{kDa}, 90 \mathrm{kDa}$, and $117 \mathrm{kDa}$. The intensity of both the major and minor bands increased after administration of DEX in the drinking water (Figs. 1, 2).
A time course of WH-412 immunoblot staining after addition of DEX to the drinking water showed that an increase of $32 \%$ was seen after only $24 \mathrm{hr}$ of treatment with DEX (Fig. 2) and a maximal increase of $50 \%$ was reached by $2 \mathrm{~d}$. The rate of increase suggests an enzyme turnover rate of approximately $1.7 \mathrm{~d}$ that was consistent with the measure of $1.43 \mathrm{~d}$ measured after $p$-chlorophenylalanine (Weissmann et al., 1990). A 50\% increase over the ADX value was seen at 2, 3, and $10 \mathrm{~d}$. This indicates that the rate of translation rose to a new steady-state level (synthesis/degradation + transport) and was not permanently activated by a de novo supply of enzyme. Unpublished observations (E. C. Azmitia, D. M. Stone, T. H. Joh, and D. H. Park) suggest that short-term ADX rats treated for $3 \mathrm{~d}$ with 


\section{SHORT-TERM ADX DORSAL RAPHE NUCLEUS}

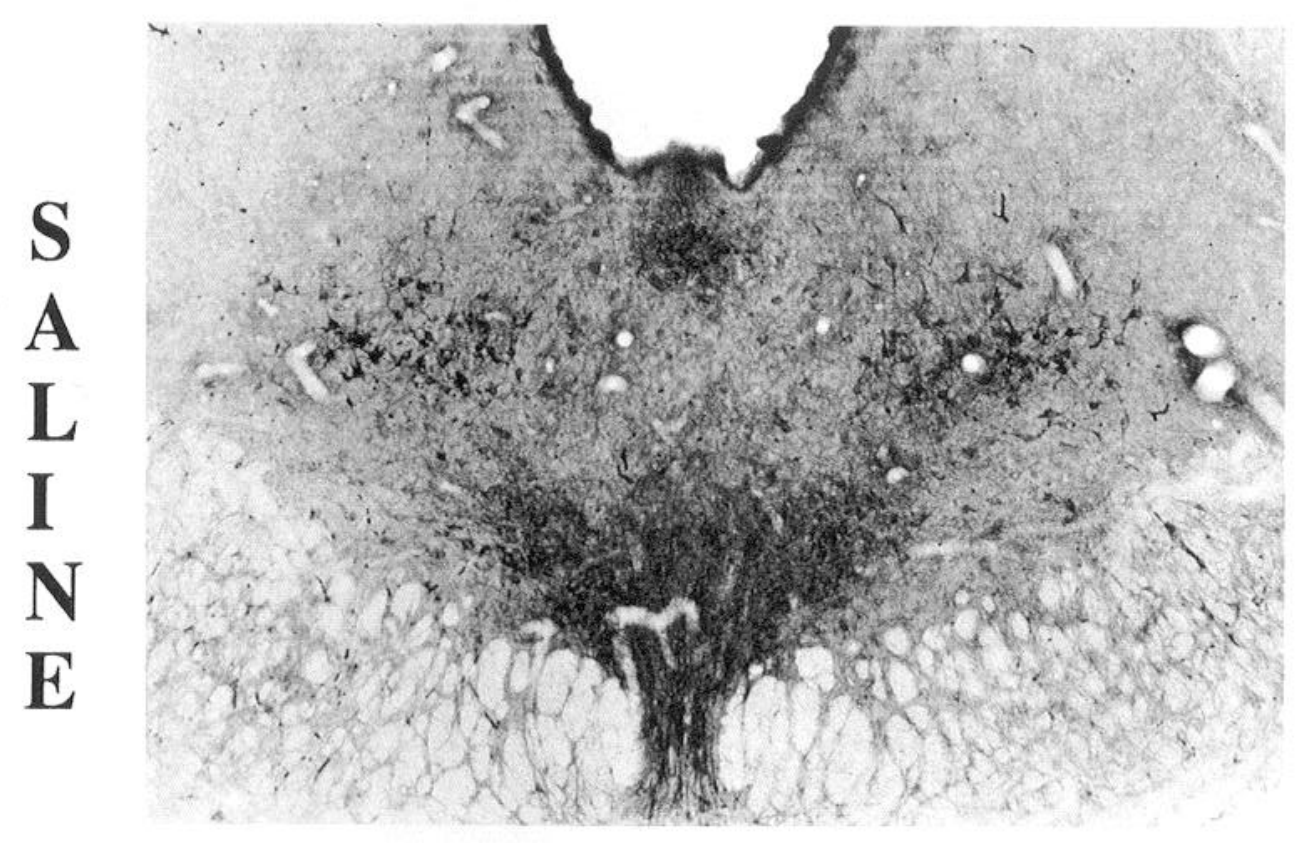

Figure 12. Photograph shows the main extent of the DRN $7 \mathrm{~d}$ after ADX given saline alone or with DEX added for the last $3 \mathrm{~d}$. The saline-treated animals show good WH-66-IR with the WH-66 antibody with individual cells seen in all subdivisions. Individual cells were not seen because of the density of labeling in the DEX-treated ADX animals. This was most apparent in the centromedian and interfascicular subdivisions where the intraneuronal space was filled with heavily labeled processes. This was best appreciated in the lateral wing subdivision of the DRN. Scale bar, $200 \mu \mathrm{m}$.

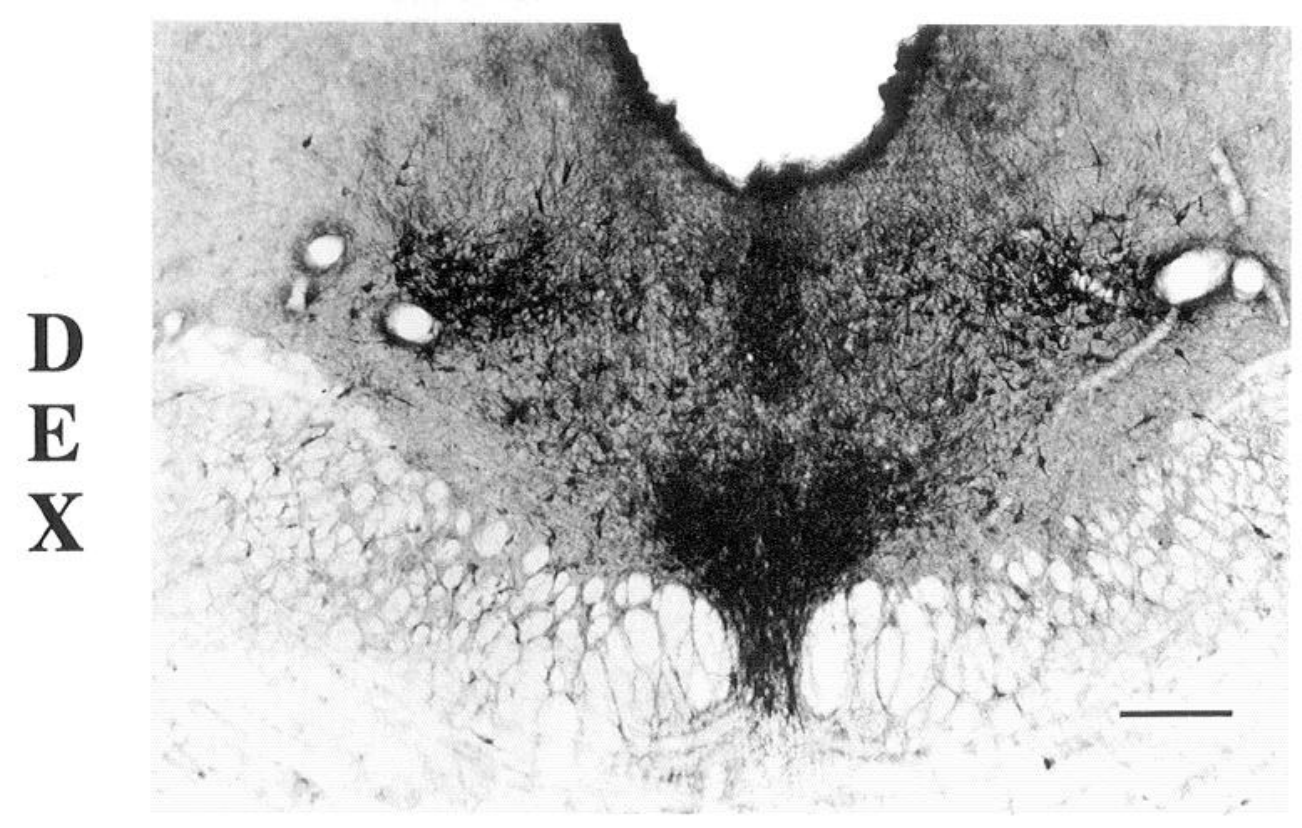

DEX do not show elevated WH mRNA levels as measured by in situ hybridization with a full-length WH probe (see Kim et al., 1991; Kim, 1992). Thus, the increase in protein amount may reflect a posttranslational mechanism that was coupled to the increase in soma size (see below).

In our preparation, the increase in WH-66-IR was accompanied by an increase in the size of neuronal dendrites and perikaryon. Most of the raphe nuclei showed increased WH66-IR staining due to an increase in the amount of WH-66IR in the perikarya and primary dendrites of the neurons. Morphometric analysis of the perikarya area revealed an increase of $80 \%$ in the lateral wings of the DRN that was sufficient to account for the increase in both the image intensity readings of the immunocytochemically stained neurons and in the densitometry measures from $49 \mathrm{kDa}$ bands in the immunoblots. In the WH-66-IR neurons of the SLN, the increase in somal area only partially compensated for the increased in the intensity of WH-66-IR.

It may be proposed that the increase in WH-66-IR was secondary to the changes in cytoplasmic area in the soma and dendrites. Similar effects of adrenalectomy on somal area in ADX rats have been reported in the hippocampus. Adrenalec- 


\section{LONG-TERM ADX DORSAL RAPHE NUCLEUS}
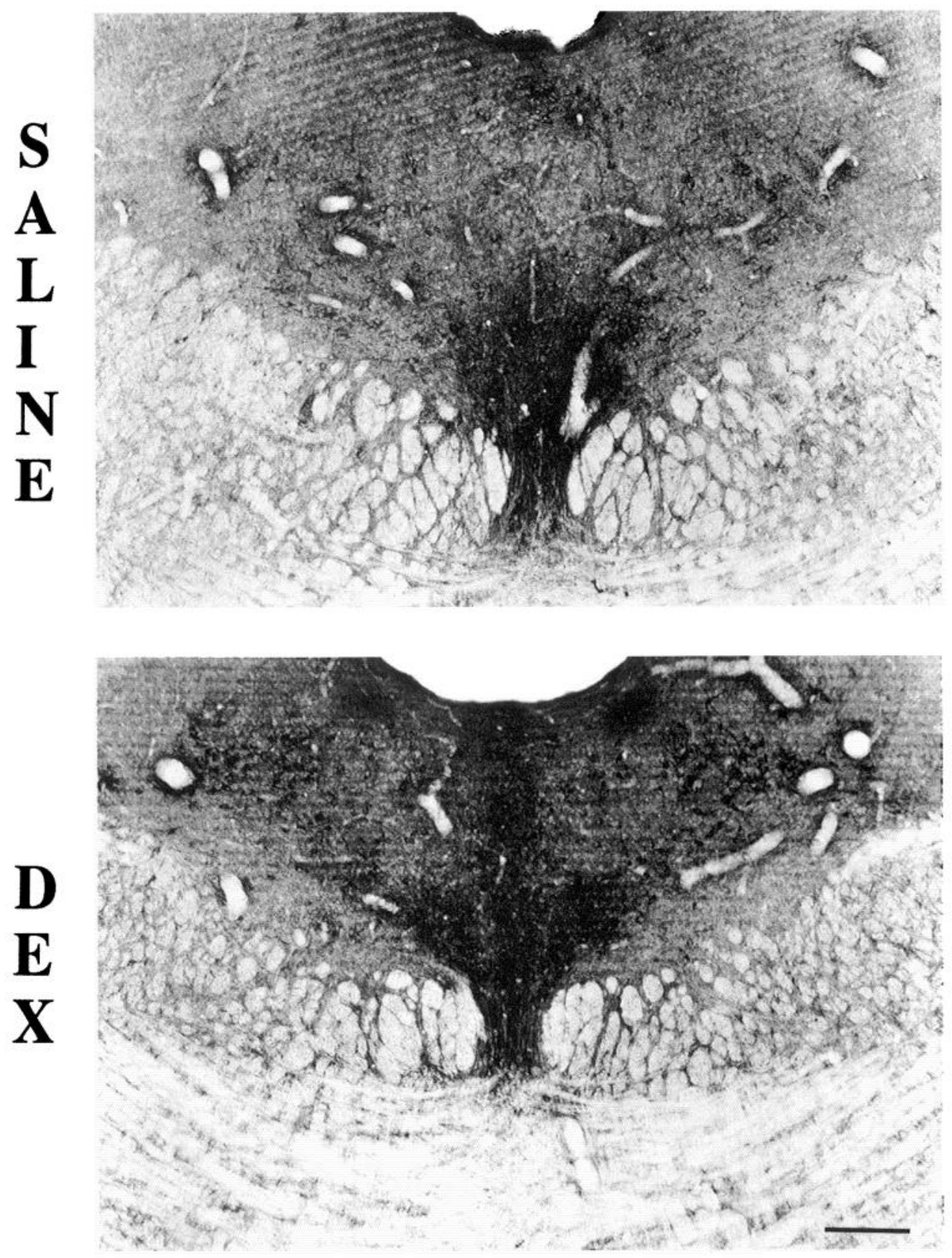

Figure 13. Photograph shows the main extent of the DRN 2 weeks after ADX given saline alone or with DEX added for the last $3 \mathrm{~d}$. The saline-treated brains show weak WH-66-IR with the WH66 antibody, especially in the lateral wings and the centromedian subdivisions. The WH-66-IR neurons in the DEX-treated animals were well stained, but the processes were not as clearly visible as seen in the short-term ADX rats. This can best be appreciated in the neurons of the lateral wings of the DRN, where only the occasional process was visible. Scale bar, $200 \mu \mathrm{m}$. tomy on day 21 results in a decrease in dendritic branching of lower-order dendrites of hippocampal granule cells at $42 \mathrm{~d}$ of age (Hashimoto et al., 1989). In young animals short-term (3$7 \mathrm{~d}$ ) ADX produces a significant decrease in granule cell area and dendritic branching (Gould et al., 1990). These effects in the hippocampus are associated with an increase in the number of pyknotic cells at short times (Gould et al., 1990; Woolley et al., 1991) and at long times a decrease in the number of granule neurons labeled with a Nissl stain and calbindin (Sloviter et al., 1989, 1993; Roy et al., 1990) and a decrease in the molecular area of the dentate gyrus (Liao et al., 1993).
The hippocampal neurons contain high levels both of corticosterone type I (aldosterone) and type II (dexamethasone, RU28362) receptors. In the hippocampus, aldosterone is more effective than RU28362 in reducing the number of pyknotic cells in granule layer of the dentate gyrus seen in short-term $A D X$ rats, suggesting that type I receptors mediate this effect (Woolley et al., 1991). However, the loss of 5-HT $\mathrm{HA}_{\mathrm{A}} \mathrm{mRNA}$, the reduced molecular layer, and Nissl labeling of the granular layer seen in long-term $A D X$ dentate gyrus are reversed by short-term exposure to a type II receptor agonist (Liao et al., 1993). The midbrain raphe neurons contain only type II corticosterone re- 
Table 1. The computer measurements of the intensity of WH-66-IR per cell, the soma cell area, and the ratio of intensity : area of 10 WH-66-IR neurons from either the lateral wing (LW) of the DRN or the neurons of the supralemniscal nucleus (B9) are shown in ADX rats with or without DEX treatment

\begin{tabular}{llll} 
Treatment & Intensity & Cell area $\left(\mu \mathrm{m}^{2}\right)$ & I/CA \\
\hline ADX, DRN-LW & $20+4$ & $167.5+26$ & $0.1194+0.015$ \\
ADX + DEX, DRN-LW & $36+4^{*}$ & $300.0+48^{*}$ & $0.1185+0.026$ \\
$\quad(\%$ of ADX) & $(180 \%)$ & $(179.1 \%)$ & $(101 \%)$ \\
ADX, B9 & $22+8$ & $171.3+40$ & $0.119+0.0257$ \\
ADX + DEX, B9 & $39+7$ & $234.6+40$ & $0.1530+0.012$ \\
$\quad(\%$ of ADX) & $(176 \%)$ & $(137 \%)$ & $(129 \%)$
\end{tabular}

The results are presented as the average + SD. I/CA is intensity over cell area.

${ }^{*} p<0.05$, two-tailed Student's $t$ test.

ceptors (Reul and deKloet, 1985; McEwen et al., 1986; Funder and Sheppard, 1987).

Previous studies have shown that the activity of WH in ADX rats could be increased by replacement with adrenal steroids. In rats ADX for a week, a $107 \%$ increase in the activity of WH in the midbrain was seen after daily injections of $1 \mathrm{mg}$ of corticosterone for $5 \mathrm{~d}$ before death (Azmitia and McEwen, 1969). Similarly, rats ADX for $8 \mathrm{~d}$ and treated with DEX $(500 \mu \mathrm{g} / \mathrm{d})$ for the last $5 \mathrm{~d}$ also showed an increase in WH activity in midbrain (47\%) and cortex (60\%) (Singh et al., 1990). In this latter report, the increase in WH activity was resistant to alkaline phosphatase treatment and was not attributed to an increase in phosphorylation of the cnzymc (Hamon ct al., 1978). Furthermore, aldosterone was without effect and the effect of chronic treatment was proposed to occur through the type II corticosterone receptor, which has an extensive distribution throughout the brain (Reul and deKloet, 1985; McEwen et al., 1986; Funder and Shephard, 1987). These results were consistent with the changes seen in our immunoblot analysis and the densitometry measures reported here. The previous observations that WH activity was increased after chronic stressors in normal but not ADX rats (Azmitia and McEwen, 1976; Boadle-Biber et al., 1989) indicate that these changes in WH activity are physiologically relevant. Changes in 5-HT turnover after stress and ADX have been reported (Thierry et al., 1968; Azmitia et al., 1970; DeKloet et al., 1982).

Glucocorticoids have been shown to change the transcriptional rate of only a few proteins by acting through the steroid promotor sequence (Yamamoto, 1985). There is a decrease of $60 \%$ in glial fibrillary acidic protein (GFAP) mRNA in rat brain after $8 \mathrm{hr}$ (Nichols et al., 1990). The decrease was due to activation of the type II corticosterone receptor since RU 28362 was the most effective steroid in decreasing GFAP mRNA. This drop in mRNA levels was accompanied by a corresponding decrease in GFAP tissue levels (O'Callaghan et al., 1991). These reports again implicate the type II corticosterone receptor in the regulation of a brain protein.

An increase in the mRNA for TH in locus coeruleus have been reported after isolation stress (Angulo et al., 1991). The changes were $18 \%, 42 \%$, or $68 \%$ above control after 7,14 , or $28 \mathrm{~d}$ of isolation stress, respectively. The long delay in this increase argues against a direct regulation by adrenal steroids on the transcriptional levels of TH in the locus coeruleus. This was in contrast to the rapid increase in TH activity seen after a variety of treatments (Zigmond, 1988). These results with TH activation provide evidence for increase protein amounts before an increase in mRNA.
The fact that adrenal steroids can influence the expression of a structural protein in hippocampal astrocytes (Nichols et al., 1990) raises the possibility that structural proteins in neurons may be regulated by adrenal steroids, and secondarily produce an increase in the levels of transmitter-related proteins without a change in transcription. It fact, nuclear runoff assays of WH gene transcription rates revealed similar levels of gene expression for pineal and midbrain although the RNase protection assay showed much higher steady-state mRNA levels in pineal than in midbrain (Hart et al., 1991). These authors concluded that the control of WH mRNA levels was posttranscriptional, which agrees with the findings showing a greater translational efficiency in brain (Dumas et al., 1989). These authors found that although the level of WH mRNA was at least 150 times lower in the raphe nuclei than in the pineal, the WH antigen was three times more abundant in raphe than pineal. The mechanism of posttranslation modification remains to be determined, but may involve structural proteins since our results indicate that the greater level of WH immunoreactivity seen after DEX treatment was correlated to an increase in soma area.

\section{References}

Angulo JA, Printz D, Ledoux M, McEwen BS (1991) Isolation stress increases tyrosine hydroxylase mRNA in the locus coeruleus and midbrain and decreases proenkephalin mRNA in the striatum and nucleus accumbens. Mol Brain Res 11:301-308.

Azmitia EC (1978) The serotonin producing neurons of the midbrain median and dorsal raphe nuclei. In: The handbook of psychopharmacology, Vol 9 (Iversen LL, Iversen SD, Snyder S, eds), pp 233314. New York: Plenum.

Azmitia EC, McEwen BS (1969) Corticosterone regulation of tryptophan hydroxylase in midbrain of the rat. Science 166:1274-1276.

Azmitia EC, McEwen BS (1974) Adrenalcortical influence on rat brain tryptophan hydroxylase activity. Brain Res 78:291-302.

Azmitia EC, McEwen BS (1976) Early response of rat brain tryptophan hydroxylasc activity to cycloheximide, puromycin and corticosterone. J Neurochem 27:773-778.

Azmitia EC, Algeri S, Costa E (1970) In vivo conversion of ${ }^{3} \mathrm{H}-\mathrm{L}-$ tryptophan into ${ }^{3} \mathrm{H}-\mathrm{L}$-serotonin in brain areas of adrenalectomized rats. Science 169:201-203.

Azmitia EC, Yu IJ, Akbari HM, Chen Y, Marshak DR (1991) Antipeptide antibodies against rat brain tryptophan hydroxylase. Soc Neurosci Abstr 17:1488.

Azmitia EC, Yu I, Akbari HM, Kheck N, Whitaker-Azmitia PM, Marshak DR (1992) Antipeptide antibodies against the 5-HT ${ }_{1 A}$ receptor. J Chem Neuroanat 5:289-298.

Boadle-Biber MC, Corley KC, Graves L, Phan T, Rosecrans J (1989) Increase in the activity of tryptophan hydroxylase from cortex and midbrain of male Fischer 344 rats in response to acute or repeated sound stress. Brain Res 482:306-316.

Cash CD, Vayer P, Mandel P, Maitre M (1985) Tryptophan-5-hydroxylase. Rapid purification from whole rat brain and production of specific antiserum. Eur J Biochem 149:239-254. 
Darmon MC, Grima B, Cash CD, Maitre M, Mallet J (1986) Isolation of rat pineal gland $\mathrm{CDNA}$ clone homologous to tyrosine and phenylalanine hydroxylase. FEBS Lett 206:43-46.

Darmon MC, Guibert B, Leviel V, Ehert M, Maitre M, Mallet J (1988) Sequence of two mRNAs encoding active rat tryptophan hydroxylase. J Neurochem 51:312-316.

DeKloet ER, Kovacs GL, Szabo G, Telegdy G, Bohus B, Versteeg DHG (1982) Decreased serotonin turnover in the dorsal hippocampus of rat brain shortly after adrenalectomy: selective normalization after corticosterone substitution. Brain Res 239:659-663.

Dumas S, Darmon MC, Dlort J, Mallet J (1989) Differential control of tryptophan hydroxylase expression in raphe and in pineal: evidence for a role of translation efficiency. J Neurosci Res 24:537-547.

Funder JW, Sheppard K (1987) Adrenocortical steroids and the brain. Annu Rev Physiol 49:397-411.

Gould E, Wooley CS, McEwen BS (1990) Short-term glucocorticoid manipulations affect neuronal morphology and survival in the adult dentate gyrus. Neuroscience 37:367-375.

Haan EA, Jennings IG, Cuello AC, Nakata H, Fujisawa H, Chow CW, Kushinsky R, Bittingham J, Cotton RGH (1987) Identification of serotonergic neurons in human brain by a monoclonal antibody binding to all three aromatic amino acid hydroxylases. Brain Res 426:1927.

Hamon M, Bourgoin S, Henry F, Simmonet G (1987) Activation of tryptophan hydroxylase by adenosine triphosphate, magnesium and calcium. Mol Pharmacol 14:99-110.

Hart RP, Yang R, Riley LA, Green TL (1991) Post-transcriptional control of tryptophan hydroxylase expression in rat brain stem and pineal gland. Mol Cell Neurosci 2:71-77.

Hashimoto $\mathrm{H}$ et al. (1989) Neonatal adrenalectomy alters dendritic branching of hippocampal granule cells. Exp Neurol 104:62-67.

Hollow E, Lane D (1988) Antibodies: a laboratory manual. Cold Spring Harbor, NY: Cold Spring Harbor Laboratory.

Jacobs BL, Azmitia EC (1992) The structure and function of the brain serotonergic system. Physiol Rev 72:165-229.

Joh TH, Shikimi T, Pickel VM, Reis DJ (1975) Brain tryptophan hydroxylase: purification of antibodies to and cellular and ultrastructural localization in serotonergic neurons of rat midbrain. Proc Natl Acad Sci USA 72:3575-3579.

Kim KS (1992) Use of polymerase chain reaction techniques in tryptophan hydroxylase gene analysis. J Chem Neuroanat 5:279-280.

Kim KS, Wessel TC, Stone DM, Carver CH, Joh TH, Park DH (1991) Molecular cloning and characterization of cDNA encoding tryptophan hydroxylase from rat central serotonergic neurons. Mol Brain Res 9:277-283.

Liao B, Azmitia EC (1992) Increase of tryptophan hydroxylase enzyme by dexamethasone in adrenalectomized rat midbrain using western blots and immunocytochemistry with antipeptide antibodies. Soc Neurosci Abstr 18:820.

Liao B, Miesak B, Azmitia EC (1993) Loss of 5-HT ${ }_{1 A}$ receptor mRNA in the dentate gyrus of the long-term adrenalectomized rats and rapid reversal by dexamethasone. Mol Brain Res, in press.
McEwen BS, deKloet ER, Rostene W (1986) Adrenal steroid receptors and actions in the nervous system. Physiol Rev 66:1121-1188.

Nakata H, Fujisawa H (1982) Purification and properties of tryptophan 5-monoxygenase from rat brain-stem. Eur J Biochem 122:4147.

Nichols NR, Osterburg HH, Masters JN, Millar SL, Finch CE (1990) Messenger RNA for glial fibrillary acidic protein is decreased in rat brain following acute or chronic corticosterone treatment. Mol Brain Res 7:1-7.

O'Callaghan JP, Brinton RE, McEwen BS (1991) Glucocorticoids regulate the concentration of glial acidic proteins throughout the brain. Brain Res 57:860-869.

Reul JMHM, deKloet ER (1985) Two receptor systems for corticosterone in rat brain: microdistribution and differential occupation. Endocrinology 117:2505-2511.

Roy EJ, Lynn DM, Bemm CW (1990) Individual variations in hippocampal dentate degeneration following adrenalectomy. Behav Neural Biol 54:330-336.

Singh VB, Corley KC, Phan H, Boadle-Biber MC. (1990) Increases in the activity of tryptophan hydroxylase from rat cortex and midbrain in response to acute or repeated sound stress are blocked by adrenalcctomy and restored by dexamethasone treatment. Brain Res 516: 66-76.

Sloviter RS, Valiquette G, Abrams GM, Ronk EC, Sollas AL, Paul LA, Neubort S (1989) Selective loss of hippocampal granule cells in the mature rat brain after adrenalectomy. Science 243:535-538.

Thierry A-M, Fekete M, Glowinski J (1968) Effects of stress on the metabolism of noradrenaline, dopamine and serotonin $(5-\mathrm{HT})$ in the central nervous system of the rat. II. Modifications of serotonin metabolism. Eur J Pharmacol 4:384-389.

Törk I, Halliday M, Cotton RGH (1992) Application of antiphenylalanine hydroxylase antibodies to the study of the serotonergic system in the human brain. J Chem Neuroanat 5:311-313.

Weissmann D, Belin MF, Aguera M, Meunier C, Maitre M, Cash CD, Ehret M, Mandel P, Pujol JF (1987) Immunohistochemistry of tryptophan hydroxylase in the rat brain. Neuroscience 23:291-304.

Weissmann D, Chamba G, Debure L, Rousset C, Richard F, Maitre M, Pujol JF (1990) Variation of tryptophan-5-hydroxylase concentration in the rat raphe dorsalis nucleus after $p$-chlorophenylalanine administration. II. Anatomical distribution of the tryptophan-5-hydroxylase protein and regional variation of its turnover rate. Brain Res 536:46-55.

Woolley CS, Gould E, Sakai RR, Spencer RL, McEwen BS (1991) Effects of aldosterone or RU28362 treatment on adrenalectomy-induced cell death in the dentate gyrus of the adult rat. Brain Res 554: 312-315.

Yamamoto KR (1985) Steroid receptor regulated transcription of specific genes and gene networks. Annu Rev Genet 19:209-252.

Zigmond R (1988) A comparison of the long-term and short-term regulation of tyrosine hydroxylase activity. J Physiol (Paris) 83:267271. 